\title{
Transcription Factor COE1
}

National Cancer Institute

\section{Source}

National Cancer Institute. Transcription Factor COE1. NCI Thesaurus. Code C80025.

Transcription factor COE1 (591 aa, $64 \mathrm{kDa}$ ) is encoded by the human EBF1 gene. This protein plays a role in the promotion of transcription. 